\title{
Pengaruh Strategi Bisnis, Pendelegasian Wewenang, Kepemimpinan, Kebijakan Manajemen Keuangan Dan Manajemen Likuiditas Terhadap Manajemen Laba Pada Yayasan Nirlaba Yarsi Sumatera Barat
}

\author{
Afridian Wirahadi Ahmad ${ }^{1}$, Risa Astuti ${ }^{2}$ \\ 1,2 Jurusan Akuntansi Politeknik Negeri Padang
}

\begin{abstract}
English)
This study aims to examine the effect of business strategy, delegation of authority, leadership, financial management policies and liquidity management on earnings management. This research was conducted at the Islamic Hospital Foundation (YARSI) West Sumatra. This type of research is a quantitative causality research using a questionnaire. The population of this research is the leadership of the foundation and the head of the business unit in Yarsi, West Sumatra. All members of the population were sampled in the study. The results showed that (1) business strategy has no positive effect on earnings management, (2) delegation of authority has no positive effect on earnings management, (3) leadership has a negative effect on earnings management, (4) financial management policies have no positive effect on earnings management. , (5) liquidity management has no positive effect on earnings management
\end{abstract}

Abstrak (Bahasa Indonesia)

Penelitian ini bertujuan untuk menguji pengaruh strategi bisnis, pendelegasian wewenang, kepemimpinan, kebijakan manajemen keuangan dan manajemen likuiditas terhadap manajemen laba. Penelitian ini dilakukan di Yayasan Rumah Sakit Islam (YARSI) Sumatera Barat. Jenis penelitian ini merupakan penelitian kuantitatif kausalitas dengan menggunakan kuesioner. Populasi dari penelitian adalah Pimpinan Yayasan dan Pimpinan unit usaha ada di Yarsi Sumatera Barat. Semua anggota popluasi menjadi sampel dalam penelitian. Hasil penelitian menunjukkan bahwa (1) strategi bisnis tidak berpengaruh positif terhadap manajemen laba, (2) pendelegasian wewenang tidak berpengaruh positif terhadap manajemen laba, (3) kepemimpinan berpengaruh negative terhadap manajemen laba, (4) kebijakan manajemen keuangan tidak berpengaruh positif terhadap manajemen laba, (5) manajemen likuiditas tidak berpengaruh positif terhadap manajemen laba

Keyword: Earnings Management, Business Strategy, Delegation of Authority, Leadership, Financial Management Policies, Liquidity Management, Foundations

Corresponding author: Afridian Wirahadi Ahmad (afridianpadang@gmail.com)

\section{Pendahuluan}

Pertumbuhan ekonomi dan implikasi globalisasi menuntut semua jenis bidang usaha untuk dapat menciptakan keunggulan yang kompetitif di bidangnya agar dapat bertahan dan bersaing dalam lingkungan bisnis yang memiliki ketidakpastian yang tinggi. Menurut Paylosa (2014), dalam menghadapi ketidakpastian yang tinggi manajemen harus memiliki alat untuk membantu mereka dalam merencanakan dan mengalokasikan sumber daya yang terbatas. Sumber daya harus dimanfaatkan secara efektif dan efisien dalam menjalankan kegiatan operasional agar dapat membantu perusahaan memenangkan 
persaingan pasar yang kompetitif. Karenanya, perusahaan akan cenderung menampilkan kinerja terbaiknya.

Salah satu alat ukur yang digunakan untuk mengukur kinerja suatu perusahaan adalah melalui laporan keuangan (Brigita dan Adiwibowo, 2017). Menurut Astari dan Suryana (2017) laporan keuangan menjadi perhatian utama bagi penggunanya dalam proses pengambilan keputusan untuk itu laporan keuangan harus disajikan dengan tepat dan sesuai dengan standar akuntansi keuangan yang berlaku. Tujuan laporan keuangan menurut Pernyataan Standar Akuntansi Keuangan (PSAK) adalah menyediakan informasi yang mengenai posisi keuangan, kinerja keuangan, dan arus kas entitas yang bermanfaat bagi sebagian besar kalangan pengguna laporan yang dijadikan sebagai dasar dalam pengambilan keputusan serta sebagai pertanggungjawaban manajemen atas penggunaan sumber daya yang dipercayakan kepada mereka.

Laba merupakan salah satu indikator penting yang digunakan untuk mengukur kinerja manajemen (Novilia dan Nugroho, 2016). Statement of Financial Accounting Concept (SFAC) No.1 menyebutkan informasi laba merupakan komponen laporan keuangan yang disediakan dengan tujuan untuk menilai kinerja manajemen. Oleh karena itu manajer akan cenderung menunjukkan kinerja terbaiknya dengan cara pengelolaan terhadap angka laba (manajemen laba) (Wiryadi dan Sebrina, 2013).

Manajemen laba menurut Astari dan Suryanawa (2017) dalam Schipper (1989) adalah campur tangan manajemen dalam proses penyusunan laporan keuangan bagi pihak eksternal sehingga dapat meratakan, menaikkan, dan menurunkan laba. Menurut Sanjaya dan Raharjo (2006) manajemen laba terjadi ketika manajemen menggunakan judgment dalam laporan keuangan strukturisasi transaksi-transaksi dengan maksud untuk menyesatkan beberapa stakeholder tentang kinerja perusahaan namun masih dalam batasan akuntansi yang berlaku seperti Generally Accepted Accounting Principles (GAAP). Standar akuntansi memperbolehkan manajer suatu perusahaan untuk mengevaluasi persiapan laporan keuangan keuangan perusahaan. Atik (2009) dalam Niranda dan Muid (2020) manajer mempunyai peluang untuk melakukan praktik manjemen laba terhadap laporan keuangan dan manajer juga diperkenankan untuk memilih dan mengubah metode akuntansi menggunakan penilaian manajer untuk meningkatkan, menurunkan, atau melakukan pemerataan laba. Hal ini didukung oleh adanya teori agensi yang menjelaskan hubungan antara agent dan principal, dimana principal memberikan kewenangan kepada agent untuk mengelola perusahaan dan membuat keputusan yang menguntungkan.

Menurut Healy dan Wahlen (1999) manajemen melakukan manajemen laba karena didorong oleh beberapa motivasi yang terdiri dari pasar modal, kontrak dan regulator. Sedangkan menurut Scott (2000) 
manajemen laba yang dilakukan oleh manajer karena tujuan bonus, perjanjian hutang, motivasi politik, motivasi pajak, pergantian CEO, penawaran saham perdana, dan motivasi komunikasi investor. Manajemen laba dengan menurunkan atau menaikkan laba tergantung pada kebutuhan dan tujuan perusahaan.

Salah satu faktor yang mempengaruhi manajemen laba adalah strategi bisnis (Wardani dan Isbela, 2017). Strategi bisnis menurut Kotler dan Keller (2009) dalam Daud, et al (2020) merupakan suatu perencanaan dan pelaksanaan untuk mencapai tujuan perusahaan. Strategi bisnis dapat dilakukan dengan menganalisis lingkungan, baik lingkungan internal maupun eksternal. Peran seorang manajer sangat diperlukan dalam pemilihan strategi yang baik bagi perusahaan terutama dalam kondisi ketidakpastian ekonomi. Strategi bisnis memotivasi manajer untuk melakukan manajemen laba demi memaksimalkan kepentingan pribadinya.

Kinerja perusahaan adalah hasil dari kinerja manajemen untuk mencapai tujuan perusahaan. Tujuan perusahaan adalah memberikan kemakmuran yang adil bagi pemiliknya. Kemakmuran bagi pemilik usaha dapat dilihat dari kinerja dan nilai perusahaan yang maksimum. Kinerja memiliki hubungan yang erat dengan laba (Puspita, 2018). Perusahaan yang dinilai mempunyai kinerja baik memiliki laba yang tinggi, sebaliknya perusahaan yang mempunyai kinerja buruk dianggap memiliki laba rendah. Tinggi rendahnya laba memotivasi manajemen melakukan pengaturan laba. Baik buruknya kinerja dapat dipengaruhi oleh pendelegasian wewenang dan kepemimpinan dalam suatu perusahaan. Pendelegasian wewenang adalah pemberian wewenang dan tanggung jawab oleh pemberi wewenang (delegator) kepada penerima wewenang (delegate) dan bekerja atas nama delegator. Pendelegasian yang baik akan meningkatkan kinerja karyawan dalam bekerja. Kepemimpinan adalah kemampuan untuk mempengaruhi suatu kelompok kearah untuk mencapai serangkaian tujuan. Hasibuan dan Bahri (2018) apabila kepempinan suatu perusahaan baik maka kinerja organisasi juga akan membaik.

Nilai perusahaan yang maksimum dapat diwujudkan melalui kebijakan manajemen keuangan yang tepat sehingga perusahaan berpeluang mendapatkan keuntungan yang optimal dan kinerja perusahaan akan bernilai baik. Manajemen keuangan adalah area yang dapat meningkatkan nilai perusahaan melalui kebijakan yang diambil. Penelitian Cahyaningdyah dan Ressany (2012) pemilihan kebijakan keuangan yang tepat dapat meningkatkan nilai perusahaan.

Manajemen likuiditas adalah kemampuan manajemen perusahaan dalam memenuhi kewajiban finansial jangka pendek pada saat jatuh tempo. Perusahaan yang mampu memenuhi kewajiban jangka pendeknya 
tepat waktu menunjukkan perusahaan tersebut mempunyai aktiva lancar yang lebih besar daripada kewajibannya (Nurakhriroh, 2014). Likuiditas perusahaan ditunjukkan dari besar kecilnya aktiva lancar, yaitu aktiva yang mudah dikonversi menjadi kas meliputi kas, surat berharga, piutang persediaan. Likuiditas yang tinggi menyebabkan kinerja perusahaan dinilai buruk karena adanya idle cash dan likuiditas yang terlalu rendah juga akan dinilai buruk karena perusahaan tidak mampu memenuhi kewajiban lancarnya. Oleh sebab itu diperlukan manajemen likuiditas yang baik agar perusahaan dapat menentukan rasio likuiditas yang tepat untuk meningkatkan kinerjanya (Apriyanti, 2018).

Salah satu organisasi yang melakukan manajemen laba yaitu Yayasan Rumah Sakit Islam Sumatera Barat atau disingkat dengan YARSI Sumatera Barat merupakan yayasan yang berada di Sumatera Barat, berdiri sejak tahun 1969 atas prakarsa Bapak Mohammad Natsir. Yayasan ini merupakan yayasan yang memiliki aset terbesar di Sumatera Barat yakni lebih dari 360 Milyar rupiah. Yayasan ini mengelola 2 (dua) unit Perguruan Tinggi dan 6 (enam) unit Rumah Sakit yang tersebar di beberapa wilayah di Sumatera Barat, dikenal dengan Rumah Sakit Islam Ibnu Sina (RSI Ibu Sina). Berdasarkan hasil observasi dan wawancara dengan pimpinan Yayasan, Yarsi telah menerapkan manajemen laba dengan cara diantaranya menggunakan kebijakan akuntansi dan menggeser periode pengakuan pendapatan. Adapun salah satu tujuan menurunkan angka laba karena didorong oleh motivasi pajak. Bisnis rumah sakit dan perguruan tinggi yang dikelola tidak berbentuk Perseroan Terbatas yang cenderung berorientasi pada laba, namun dilakukan berbentuk Yayasan yang cenderung berorientasi pada nirlaba. Hal ini menjadi ketertarikan peneliti mengambil objek penelitian pada Yarsi Sumatera Barat.

\section{Literatur Review dan Pengembangan Hipotesis}

\section{Agency Theory}

Jensen dan Meckling (1976) mendefinisikan agency theory sebagai hubungan keagenan sebagai kontrak dimana satu atau lebih (pemilik) melibatkan orang lain (agen) untuk melakukan pekerjaan atas nama pemilik melalui pendelegasian wewenang oleh pemilik kepada agen. Dalam teori ini menjelaskan adanya konflik kepentingan yang terjadi antara agen (manajer) dengan principal (pemilik). Konflik ini terjadi karena pemilik tidak dapat selalu memonitor setiap aktivitas agen atau manajer sehari-hari dalam menjalankan operasional bisnis perusahaan untuk memastikan bahwa agen atau manajer bekerja sesuai dengan keinginan pemilik. Agen atau manajer sebagai pengelola perusahaan mempunyai posisi yang memiliki informasi lebih daripada pemilik atau principal. Kesenjangan informasi antara agen dengan pemilik perusahaan menjadikan manajemen mempunyai kesempatan untuk memaksimalkan kepentingan mereka dengan melakukan manajemen laba (Fauziah, 2014 dalam Wardani dan Isbela, 2017). 


\section{Manajemen Laba}

Scott (1997) manajemen laba merupakan pengelolaan laba oleh manajemen dengan cara memilih kebijakan akuntansi yang sesuai dari standar akuntansi yang ada bertujuan untuk memaksimumkan kepentingannya atau niali perusahaan. Daud, et al (2020) manajemen laba merupakan penyalahgunaan keputusan tertentu dalam laporan keuangan dan transaksi untuk mengubah laporan keuangan sebagai dasar penilaian kinerja perusahaan. Healy dan Wahlen (1999) dalam Kawedar (2005) manajemen laba terjadi ketika menggunakan judgment dalam pelaporan keuangan dan membentuk transaksi yang dapat mengubah laporan keuangan dengan tujuan memanipulasi besaran laba yang dilaporkan kepada stakeholders mengenai kinerja ekonomi perusahaan. Manajemen laba dalam penelitian ini adalah praktik pengelolaan penyajian laba perusahaan dalam laporan keuangan agar terlihat baik dihadapan seluruh pemangku kepentingan.

Adapun pola manajemen laba menurut Scott (1997) adalah:

1)

Taking a Bath

Pola ini dilakukan dengan cara mengakui biaya-biaya periode mendatang pada periode berjalan.

Pola ini dilakukan apabila terjadi kondisi buruk yang tidak dapat dihindari. Akibatnya laba pada periode mendatang akan menjadi tinggi dari yang seharusnya.

2)

Income minimization

Pola ini dilakukan dengan cara meminimalkan angka laba. Pola ini dilakukan pada saat perusahaan memiliki laba yang tinggi dengan tujuan agar tidak mendapat perhatian secara politis.

Memaksimalkan laba dengan tujuan untuk memperoleh bonus yang lebih besar maupun untuk memenuhi perjanjian hutang jangka panjang (debt covenant).

4) Income smoothing

Pola ini dilakukan dengan cara meratakan laba yang dilaporkan untuk mengurangi laba yang berfluktuasi yang terlalu besar karena investor lebih menyukai laba yang relative stabil

\section{Strategi Bisnis}

Griffin (2000) dalam buku Sule dan Saefullah (2005) mendefenisikan strategi sebagai rencana komprehensif untuk mencapai tujuan organisasi. Tidak hanya mencapai tujuan organisasi, tetapi strategi juga dimaksudkan untuk mempertahankan keberlangsungan organisasi. Menurut Paylosa (2014) strategi bisnis merupakan perencanaan terintegrasi dengan mempertimbangkan aspek strategik dalam perusahaan. Daud, et al (2020) penerapan strategi bisnis menjadi tugas penting bagi manajerial dalam mencapai kesuksesan organisasi. Dalam menerapkan strategi perusahaan manajerial harus melakukan penilaian 
secara efektif dan efisien dalam mengembangkan kebutuhan dan kemampuan organisasi dalam mencapai pencapaian dan sasaran perusahaan. Hal ini dikarenakan pemilihan strategi yang tepat akan menciptakan kinerja yang unggul bagi perusahaan (1980) dalam Puspita (2018).

\section{Pendelegasian wewenang}

Pendelegasian ialah pelimpahan kekuasaan, wewenang dan tanggung jawab kepada orang lain (Hermawan, 2019). Sedangkan wewenang menurut Irwan (2013) dalam Fazira dan Erdawati (2019) adalah hak seseorang untuk mengambil tindakan yang diperlukan agar tugas serta tanggung jawabnya dapat dilaksanakan dengan baik. Pendelegasian wewenang adalah memberikan sebagian pekerjaan atau wewenang oleh delegator (pemberi wewenang) kepada delegate (penerima wewenang) untuk dikerjakannya atas nama delegator (Muttaqin, 2018).

\section{Kepemimpinan}

Kepemimpinan menurut Robbins (1999) dalam Suryana, Haerani dan Taba ialah sebagai kemampuan untuk mempengaruhi suatu kelompok kearah tercapainya tujuan. Hasibuan (2005) menyatakan kepemimpinan adalah cara seorang pemimpin mempengaruhi perilaku bawahan, agar mau bekerjasama dan bekerja secara produktif untuk mencapai tujuan organisasi. Santoso (2013) kepemimpinan (leadership) sebagai kemampuan seseorang untuk mempengaruhi suatu kelompok dengan maksud untuk mencapai sebuah visi atau serangkaian tujuan yang ditetapkan.

\section{Kebijakan manajemen keuangan}

Manajemen keuangan merupakan salah satu area yang dapat dipakai untuk meningkatkan nilai perusahaan melalui kebijakan-kebijakan yang diambil (Cahyaningdyah dan Ressany, 2012). Maksimalisasi nilai perusahaan merupakan salah satu wujud tercapainya tujuan perusahaan. Adanya pencapaian tujuan oleh perusahaan, menjadikan perusahaan berpeluang mendapatkan keuantungan yang optimal sehingga kinerja perusahaan juga akan dinilai baik (Murtini, 2008). Terdapat tiga kebijakan manajemen keuangan yaitu kebijakan pendanaan, kebjaka investasi dan kebijkan dividen.

\section{Manajemen likuiditas}

Manajemen likuiditas adalah kemampuan manajemen perusahaan untuk menyediakan dana yang cukup guna memenuhi kewajiban jangka pendeknya (Apriyanti, 2018). Perusahaan yang likuid memiliki dana yang cukup untuk membayar kewajibannya pada saat jatuh tempo. Manajemen likuiditas melibatkan manajemen aktiva dan kewajiban jangka pendek untuk memastikan kecukupan likuiditas. Untuk 
memenuhi kewajiban perusahaan yang akan jatuh tempo, perusahaan harus memiliki tingkat ketersediaan jumlah kas yang baik atau asset lancarnya juga dapat dengan segera dikonversi atau diubah menjadi kas. Apabila tingkat likuiditas rendah cenderung membuat manajer termotivasi untuk menaikkan laba agar perusahaan tersebut dinilai baik karena dapat mengembalikan hutangnya menggunakan asset lancarnya (Nurakhiroh dan Jayanto, 2014).

\section{Pengembangan hipotesis}

Strategi bisnis adalah strategi yang disusun pada tingkat unit bisnis bertujuan untuk mencapai tujuan perusahaan serta menjaga keberlangsungan suatu organisasi (Daud, et al). Penerapan strategi bisnis merupakan tugas penting bagi manajerial. Pemilihan strategi bisnis yang tepat dapat menciptakan nilai yang superior bagi perusahaan. Berdasarkan teori keagenan menyatakan bahwa agen (manajemer) di perusahaan akan cenderung membuat keputusan yang dapat memaksimalkan kepentingannya sendiri karena agen lebih memiliki informasi yang lengkap dibandingkan dengan prinsipal (pemilik). Agen (manajer) memaksimalkan kepentingannya dengan cara melakukan manajemen laba dimana lingkungan dan strategi dapat memotivasi manajer untuk melakukan hal tersebut. Hal ini membuktikan bahwa strategi bisnis dapat mempengaruhi manajemen untuk melakukan manajemen laba

Hasil penelitian yang dilakukan oleh Puspita (2018) menyatakan bahwa manajer akan cenderung memaksimalkan kepentingan pribadinya dengan melakukan manajemen laba dimana strategi bisnis memotivasi perusahaan untuk melakukan hal tersebut sehingga strategi bisnis berpengaruh terhadap manajemen laba. Hal ini berbeda dengan penelitian Wardani dan Isbela (2017) dan penelitian Daud, et al (2020) yang menyatakan bahwa strategi bisnis tidak berpengaruh secara signifikan terhadap manajemen laba. Berdasarkan hipotesis diperoleh praduga sebagai berikut:

\section{Hipotesis 1: Strategi bisnis berpengaruh positif terhadap manajemen laba.}

Pendelegasian wewenang adalah suatu tindakan memberikan sebagian pekerjaan atau wewenang kepada delegate (penerima wewenang) oleh delegator (pemberi wewenang) untuk dikerjakan atas nama delegator (Fazira dan Erdawati, 2019). Pendelegasian sangat perlu dilakukan untuk mengembangkan para bawahan sehingga dapat memperkuat organisasi dan terciptanya efisiensi dari fungsi-fungsi yang ada dalam organisasi. Apabila dalam suatu perusahaan tidak ada pendelegasian wewenang maka akan mengakibatkan terganggunya kegiatan dalam pencapaian tujuan organisasi tersebut. Oleh karena itu adanya pendelegasian wewenang yang lebih besar memberikan kesempatan bagi para manajer untuk membuat keputusan yang lebih baik, yang pada akhirnya dapat mengakibatkan peningkatan kinerja 
perusahaan. Hal ini dapat membuktikan bahwa pendelegasian wewenang dapat mempengaruhi manajemen untuk melakukan manajemen laba.

Hasil penelitian oleh Hermawan, (2019) menunjukkan bahwa pendelegasian wewenang berpengaruh positif dan signifikan terhadap kinerja karyawan. Semakin baik pendelegasian dalam suatu organisasi, maka akan semakin baik juga kinerja organisasi tersebut. Selanjutnya penelitian oleh Fazira dan Erdawati (2019) pendelegasian berpengaruh positif signifikan terhadap kinerja manajerial. Berdasarkan penjabaran diatas maka dapat dirumuskan hipotesis:

\section{Hipotesis 2: Pendelegasian wewenang berpengaruh positif terhadap manajemen laba}

Kepemimpinan adalah suatu proses dimana seseorang (pimpinan) mempengaruhi para bawahan agar dapat bekerjasama untuk tercapainya tujuaan organisasi. Dengan kepemimpinan dan manajemen yang kuat suatu organisasi dapat mengoptimalkan efektivitas dalam organisasinya. Menurut Hasibuan dan Bahri (2018) kepemimpinan merupakan salah saru faktor yang dapat meningkatkan kinerja organisasi. Kinerja organisasi erat kaitannya dengan laba. Organisasi yang mempunyai kinerja baik dianggap memiliki laba yang tinggi dan sebaliknya. Tinggi rendahnya laba memotivasi manajemen untuk melakukan pengaturan terhadap laba. Hal ini menunjukkan bahwa kepemimpinan dapat mempengaruhi manajemen melakukan manajemen laba.

Hasil penelitian Lina (2014) kepemimpinan mempunyai pengaruh terhadap kinerja organisasi. Sebagai seorang pemimpin sebaiknya selalu melakukan pembaharuan pengetahuan dan selalu mencari informasi terbaru yang berhubungan dengan organisasinya. Sejalan dengan penelitian Suryana, et al (2010) kepemimpinan berpengaruh pengaruh positif terhadap kinerja perusahaan Pendapat lainnya ada Hasibuan dan Bahri (2018) mengatakan bahwa apabila kepemimpinan dalam suatu organisasi baik, maka kinerja organisasi juga akan membaik. Berdasarkan penjabaran maka dapat hipotesis dalam penelitian adalah sebagai berikut:

\section{Hipotesis 3: Kepemimpinan berpengaruh positif terhadap manajemen laba}

Manajemen keuangan merupakan salah satu area yang dapat digunakan untuk meningkatkan nilai perusahaan melalui kebijakan-kebijakan yang diambil. Nilai perusahaan yang meningkat mengindikasikan perusahaan tersebut mempunyai peluang mendapatkan keuntungan yang optimal sehingga menunjukkan kinerja perusahaan yang meningkat (baik) (Murtini, 2008). Hal ini menunjukkan bahwa melalui kebijakan manajemen keuangan tepat dapat meningkatkan kinerja perusahaan sehingga kebijakan manajemen keuangan berpengaruh terhadap manajemen laba. Hasil penelitian oleh Cahyaningdyah dan Ressany (2012) terdapat pengaruh yang simultan kebijakan manajemen keuangan 
(kebijakan investasi, kebijakan pendanaan, dan kebijakan dividen) tehadap nilai perusahaan. Berdasarkan penjabaran maka hipotesis dalam penelitian adalah sebagai berikut:

\section{Hipotesis 4: kebijakan manajemen keuangan berpengaruh positif terhadap manajemen laba}

Manajemen likuiditas merupakan kemampuan manajemen perusahaan dalam memenuhi kewajiban perusahaan pada saat jatuh tempo. Prastiani (2018) rasio likuiditas dapat digunakan untuk mengukur tingkat keamanan suatu perusahaan. Namun likuiditas yang tinggi kinerja perusahaan akan dianggap kurang baik dalam mengelola kasnya karena ada kas yang menganggur dan sebaliknya bila terdapat rasio likuiditas rendah karena kelebihan kas dapat diinvenstasikan untuk memperoleh tingkat pengembalian lebih. Kondisi tersebut membuat manajer akan cenderung melakukan manajemen laba agar kinerja perusahaan tersebut dinilai baik karena dapat membayar kewajiban jangka pendeknya melalui aset lancarnya. Oleh karena itu manajemen likuiditas harus dilakukan dengan baik karena ini mengacu pada kemampuan perusahaan dalam memenuhi kewajibannya. Dengan manajemen likuiditas yang baik maka perusaaan dapat meningkatkan kinerjanya (Apriyanti, 2018). Sehingga dapat disimpulkan bahwa manajemen likuiditas berpengaruh terhadap manajemen laba. Berbeda dengan penelitian Nurakhiroh (2014) rendahnya rasio likuiditas yang menunjukkan pendapatan rendah tidak dapat memotivasi perusahaan untuk melakukan manajemen laba. Perusahaan cenderung lebih memilih menjaga likuiditasnya daripada melakukan manajemen laba, artinya likuiditas tidak berpengaruh terhadap manajemen laba. Berdasarkan pemarapan hipotesis dalam penelitian ini adalah:

\section{Hipotesis 5: Manajemen Likuiditas berpengaruh positif terhadap manajemen laba}

\section{Metode Riset}

\section{Jenis Penelitian}

Penelitian ini menggunakan jenis penelitian kuantitatif kausalitas yakni menunjukkan hubungan sebab akibat. Penelitian dilaksanakan pada tahun 2020.

\section{Populasi dan Sampel}

Populasi dalam penelitian ini adalah pimpinan pengelola Yayasan dan unit usaha yakni pengurus yayasan (kantor pusat) dan direktur atau rektor serta pimpinan setingkat dibawah direktur. Adapun pimpinan usaha terdiri dari Universitas Mohammad Natsir (UMN), Sekolah Tinggi Kesehatan (Stikes), RSI Ibnu Sina Padang, RSI Ibnu SIna Bukittinggi, RSI Ibnu Sina Padang Panjang, RSI Ibnu Sina Payakumbuh, RSI Ibnu Sina Simpang Empat, dan RSI Ibnu Sina Panti. 


\section{Sumber Data dan Teknik Pengambilan Data}

Data dalam penelitian terdiri dari data primer dan data sekunder. Data primer diperoleh melalui kuesioner dan diperkuat dengan wawancara untuk mengkonfirmasi jawaban atas kuesioner penelitian dan untuk menggali informasi yang relevan dengan tujuan penelitian Data sekunder dalam penelitian ini terdiri dari publikasi laporan keuangan, buku-buku, artikel terkait, jurnal penelitian, karya ilmiah yang berkaitan dengan masalah penelitian.

\section{Hasil dan Analisis}

\section{Uji Validitas dan Uji Reliabilitas}

Untuk melihat validitas masing-masing item kuesioner dilihat dari nilai Corrected Total-Item Correlation yakni nilai $\mathrm{r}_{\text {hitung }}>\mathrm{r}_{\text {tabel. }}$. Diketahui nilai $\mathrm{r}$ tabel adalah sebesar 0,288. Berdasarkan hasil olah data yang dilakukan diperoleh nilai Corrected Total-Item Correlation masing-masing variabel berada diatas nilai $\mathrm{r}$ tabel. Sehingga dapat disimpulkan bahwa semua item kuesioner masing-masing variabel dinyatakan valid.

Uji reliabilitas digunakan untuk mengukur keandalan variabel konstruk dan dilakukan dengan nilai Cronbach's Alpha. Hasil diperoleh nilai Cronbach's Alpha masing-masing variabel X1, X2, X3,X4, X5 dan Y adalah 0,$819 ; 0,838 ; 0,811 ; 0,755 ; 0,827 ; 0,780$. Sehingga dapat disimpulkan semua variabel dinyatakan reliable karena lebih besar dari 0,7 .

\section{Statistik Deskriptif}

Deskriptif variabel dapat dilihat dari rata-rata (mean), standar deviasi, varian, maksimum, dan minimum. Berdasarkan tabel 1 hasil uji statistic deskriptif nilai rata-rata variabel terikat (dependent) manajemen laba adalah 2,8657. Nilai rata-rata variabel bebas (independen) strategi bisnis sebesar 3,3673; pendelegasian wewenang sebesar 3,1378; kepemimpinan sebesar 3,3139; kebijakan manajemen keuangan sebesar 3,1735; dan manajemen likuiditas memiliki nilai rata-rata sebesar 3,1592. Nilai minimum variabel terikat (dependent) manajemen laba adalah 2; nilai minimum variabel bebas (independen) strategi bisnis sebesar 1,4; pendelegasian wewenang sebesar 1; kepemimpinan sebesar 1,17; kebijakan manajemen keuangan sebesar 1,30; manajemen likuiditas sebesar 1,60

Nilai maksimum variabel terikat (dependent) manajemen laba yang di peroleh berdasarkan tabel sebesar 3,71 ; nilai maksimum variabel bebas (independen) strategi bisnis sebesar 4; pendelegasian wewenang 
sebesar 4; kepemimpinan sebesar 4; kebijakan manajemen keuangan sebesar 4; manajemen likuiditas sebesar 4.

Nilai standar deviasi variabel terikat (dependent) manajemen laba adalah sebesar 0,47379; nilai standar deviasi variabel bebas (independen) strategi bisnis sebesar 0,61961; pendelegasian wewenang sebesar 0,59961; kepemimpinan sebesar 0,57154; kebijakan manajemen keuangan sebesar 0,53455; manajemen likuiditas sebesar 0,58876. Berikut disajikan tabel 1 berupa statistik deskriptif.

\section{Tabel 1}

\begin{tabular}{|c|c|c|c|c|c|}
\hline \multicolumn{6}{|c|}{$\begin{array}{l}\text { Statistik Deskriptif } \\
\text { Descriptive statistics }\end{array}$} \\
\hline & is & Manimum & Maximum & Mean & Std. Deviation \\
\hline Strategi Bisnis (XI) & 42 & 1.40 & 4.00 & 3.3679 & 61961 \\
\hline $\begin{array}{l}\text { Pindelegasuan } \\
\text { Wowenang (x2) }\end{array}$ & 49 & 100 & 400 & 3.1378 & $\$ 9961$ \\
\hline Kepemumpinan $\left(x_{3}\right)$ & 40 & 1.17 & 400 & 3.3130 & 57154 \\
\hline $\begin{array}{l}\text { Kebijakan Manqemen } \\
\text { Keuargan }\langle X 4\rangle\end{array}$ & $\Delta$ & 130 & 400 & 3.1735 & 53455 \\
\hline Manajenen thuistas $(06)$ & $a$ & 1.60 & 400 & 3.1582 & 58870 \\
\hline Manajemeni Laba (n) & 4⿻ & 2.00 & 3.71 & 2.8657 & 47370 \\
\hline Valid N (intwise) & 49 & & & & \\
\hline
\end{tabular}

\section{Uji Asumsi Klasik}

1. Pengujian normalitas dilakukan dengan One Sampel Kolmogrov Smirnov dengan nilai signifikansi $5 \%$ atau 0,05. Berdasarkan hasil uji normalitas pada tabel 2 diperoleh nilai signifikansi sebesar 0,200. Dari hasil tersebut dapat disimpulkan bahwa data terdistribusi normal sehingga model penelitian ini memenuhi uji asumsi klasik normalitas.

2. Untuk mendeteksi ada atau tidaknya multikolinearitas pada model regresi penelitian ini dapat dilihat dari: nilai tolerance dan lawannya; Variance Inflation Factor (VIF). Hasil uji multikolinearitas, nilai tolerance untuk masing-masing variabel lebih besar dari 0,1 dan nilai VIF lebih kecil dari 10 sehingga dapat dikatakan bahwa tidak terjadi masalah multikolinearitas dalam model penelitian ini.

3. Uji heteroskedastisitas dilakukan dengan melihat ada tidaknya pola tertentu pada grafik scatterplot. Berdasarkan hasil uji terlihat bahwa titik-titik menyebar secara acak serta tersebar baik di atas maupun di bawah angka 0 pada sumbu Y. Hal ini dapat disimpulkan bahwa tidak terjadi heteroskedastisitas pada model regresi. 


\section{Analisis Regresi Linear Berganda}

Analisis regresi berganda bertujuan untuk mengetahui pengaruh strategi bisnis, pendelegasian wewenang, kepemimpinan, kebijakan manajemen keuangan,dan manajemen likuiditas terhadap manajemen laba. Berdasarkan tabel 3 dapat dilihat nilai t yang menunjukkan nilai koefisien regresi variabel strategi bisnis sebesar 0,0706; nilai koefisien regresi pendelegasian wewenang sebesar 0,284; nilai koefisien regresi kepemimpinan sebesar -0,771; nilai koefisien regresi kebijakan manajemen keuangan sebesar 0,232; nilai koefisien regresi manajemen likuiditas sebesar 0,282 dan nilai konstanta sebesar 2.641.

\section{Uji Hipotesis}

\section{Koefisien Determinasi}

Koefisien determinasi berfungsi untuk untuk mengetahui berapa persen pengaruh yang diberikan variabel independen terhadap variabel dependennya. Berdasarkan tabel 2, model summary besarnya koefisien determinasi Adjusted $R^{2}$ sebesar 0,172. Angka tersebut menunjukkan besarnya persentase variasi variabel dependen yaitu manajemen laba yang dapat dijelaskan oleh variasi variabel independen yaitu strategi bisnis, pendelegasian wewenang, kepemimpinan, kebijakan manajemen keuangan, dan manajemen likuiditas adalah sebesar $17,2 \%$. Sisanya $82,8 \%$ dijelaskan oleh variabel lain yang tidak termasuk dalam penelitian ini.

Tabel 2.

\section{Koefisien Determinasi}

\begin{tabular}{l|l|l|l|l} 
& & \multicolumn{3}{c}{ Model Summary } \\
Model & R & R Square & \multicolumn{1}{c}{$\begin{array}{c}\text { Adjusted R } \\
\text { Square }\end{array}$} & \multicolumn{1}{c}{$\begin{array}{c}\text { Std. Error of the } \\
\text { Estimate }\end{array}$} \\
\hline 1 & .5099 & .259 & .172 & .43101 \\
\hline
\end{tabular}

a. Predictors: (Constant), Manajemen Likuiditas (X5), Kepemimpinan

(X3), Strategi Bisnis (X1), Pendelegasian Wewenang (X2), Kebijakan

Manajemen Keuangan (X4)

\section{Uji T}

Berdasarkan hasil uji dengan alat uji SPSS versi 25 diperoleh hasil:

a. Pengujian hipotesis 1

Hipotesis pertama (H1) dalam penelitian ini adalah strategi bisnis berpengaruh positif terhadap manajemen laba. Berdasarkan output SPSS uji T menunjukkan $t_{\text {hitung }}$ strategi bisnis (X1) sebesar 0,378 lebih kecil dari tabel 2,016 dan tingkat signifikansi sebesar 0,707. Tingkat signifikansi tersebut lebih 
besar dari 0,05 yang berarti H1 ditolak. Sehingga dapat disimpulkan bahwa variabel strategi bisnis tidak berpengaruh positif terhadap manajemen laba

b. Pengujian hipotesis 2

Hipotesis kedua (H2) penelitian ini adalah pendelegasian wewenang berpengaruh positif terhadap manajemen laba. Berdasarkan output SPSS uji T menunjukkan $t_{\text {hitung }}$ pendelegasian wewenang (X2) sebesar 1,280 lebih kecil dari $t_{\text {tabel }}$ 2,016 dengan tingkat signifikansi sebesar 0,208. Tingkat signifikansi tersebut lebih besar dari 0,05 yang artinya $\mathrm{H} 2$ ditolak. Sehingga dapat disimpulkan bahwa variabel pendelegasian wewenang tidak berpengaruh positif terhadap manajemen laba.

c. Pengujian hipotesis 3

Hipotesis ketiga (H3) penelitian ini adalah kepemimpinan berpengaruh positif terhadap manajemen laba. Berdasarkan output SPSS uji T menunjukkan thitung kepemimpinan (X3) sebesar -3.312 leih kecil dari $t_{\text {tabel }} 2,016$ dengan tingkat signifikansi sebesar 0,002. Tingkat signifikansi tersebut lebih kecil dari 0,05 namun bernilai negatif artinya $\mathrm{H} 3$ ditolak. Sehingga dapat disimpulkan bahwa variabel kepemimpinan tidak berpengaruh positif terhadap manajemen laba.

d. Pengujian hipotesis 4

Hipotesis keempat (H4) penelitian ini adalah kebijakan manajemen keuangan berpengaruh positif terhadap manajemen laba. Berdasarkan output SPSS uji T menunjukkan $t_{\text {hitung }}$ manajemen keuangan (X4) sebesar 0,803 lebih kecil dari nilai $t_{\text {tabel }}$ 2,016 dengan tingkat signifikansi sebesar 0,433. Tingkat signifikansi tersebut lebih besar dari 0,05 yang artinya H4 ditolak. Sehingga dapat disimpulkan bahwa variabel kebijakan manajemen keuangan tidak berpengaruh positif terhadap manajemen laba

e. Pengujian hipotesis 5

Hipotesis kelima (H5) penelitian ini adalah manajemen likuiditas berpengaruh positif terhadap

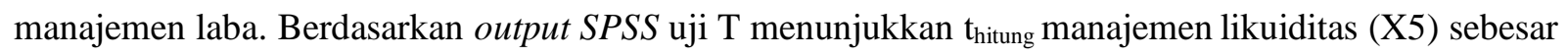
1.638 lebih kecil dari nilai $t_{\text {tabel }}$ 2,016 dengan tingkat signifikansi sebesar 0,108. Tingkat signifikansi tersebut lebih besar dari 0,05 yang artinya H5 ditolak. Sehingga dapat disimpulkan bahwa variabel. 


\section{Tabel 3.}

\section{Uji T}

\begin{tabular}{|c|c|c|c|c|c|c|}
\hline \multicolumn{7}{|c|}{ Coefficients ${ }^{a}$} \\
\hline \multirow[b]{2}{*}{ Model } & & \multicolumn{2}{|c|}{$\begin{array}{l}\text { Unstandardized } \\
\text { Coefficients }\end{array}$} & \multirow{2}{*}{$\begin{array}{c}\text { Standardized } \\
\text { Coefficients } \\
\text { Beta }\end{array}$} & \multirow[b]{2}{*}{$\mathrm{T}$} & \multirow[b]{2}{*}{ sig. } \\
\hline & & $\mathrm{B}$ & Std. Error & & & \\
\hline \multirow[t]{6}{*}{1} & (Constant) & 2.641 & 392 & & 6.732 & .000 \\
\hline & Strategi Bisnis (X1) & .076 & 202 & 100 & 378 & .707 \\
\hline & $\begin{array}{l}\text { Pendelegasian } \\
\text { Wewenang (X2) }\end{array}$ & .284 & 222 & 359 & 1.280 & .208 \\
\hline & Kepemimpinan (X3) & -.771 & 233 & -.930 & -3.312 & .002 \\
\hline & $\begin{array}{l}\text { Kebijakan Manajemen } \\
\text { Keuangan (X4) }\end{array}$ & 232 & 289 & 262 & 803 & 426 \\
\hline & $\begin{array}{l}\text { Manajemen Likuiditas } \\
(\times 5)\end{array}$ & 282 & 172 & 351 & 1.638 & 100 \\
\hline
\end{tabular}

\section{Uji F}

Uji $\mathrm{F}$ dilihat dapat dilihat dari nilai signifikansi dan membandingkan $\mathrm{F}$ tabel dengan $\mathrm{F}$ hitung. Apabila nilai signifikansi kecil dari 0,05 atau nilai $\mathrm{F}$ hasil perhitungan lebih besar dari nilai $\mathrm{F}$ tabel maka disimpulkan terdapat pengaruh simultan (bersama-sama) variabel independen terhadap variabel dependen. F tabel pada level signifikansi diperoleh sebesar 2,43.

Berdasarkan hasil uji tabel Anova tabel 4, diketahui nilai signifikansi untuk pengaruh variabel strategi bisnis (X1), pendelegasian wewenang (X2), kepemimpinan (X3), kebijakan manajemen keuangan (X4), dan manajemen likuiditas (X5) terhadap variabel manajemen laba (Y) sebesar 0,021 lebih kecil dari 0,05 dan nilai $\mathrm{F}$ hitung 3,000 lebih besar dari $\mathrm{F}$ tabel 2,43, sehingga dapat disimpulkan bahwa hipotesis keenam (H6) diterima yang berarti terdapat pengaruh variabel independen secara simultan (bersamasama) terhadap variabel dependen yaitu manajemen laba.

\section{Tabel 4}

\section{Uji F}

\begin{tabular}{|c|c|c|c|c|c|c|}
\hline \multicolumn{7}{|c|}{ ANOVA $^{a}$} \\
\hline Model & & Sum of Squares & $d f$ & Mean Square & $\mathrm{F}$ & Sig. \\
\hline \multirow[t]{3}{*}{1} & Regression & 2.787 & 5 & .557 & 3.000 & $.021^{\mathrm{b}}$ \\
\hline & Residual & 7.988 & 43 & .186 & & \\
\hline & Total & 10.775 & 48 & & & \\
\hline
\end{tabular}

a. Dependent Variable: Manajemen Laba (Y)

b. Predictors: (Constant), Manajemen Likuiditas (X5), Kepemimpinan (X3), Strategi Bisnis (X1), Pendelegasian Wewenang (X2), Kebijakan Manajemen Keuangan (X4) 


\section{Analisis}

\section{Pengaruh Strategi Bisnis Terhadap Manajemen Laba}

Berdasarkan analisis statistik pada uji $\mathrm{T}$ dalam penelitian ditemukan bahwa hipotesis pertama (H1) ditolak dan disimpulkan bahwa strategi bisnis tidak berpengaruh positif terhadap manajemen laba. Hal ini dapat dilihat dari nilai t hitung 0,368 < t tabel 2,016 dan nilai signifikansi 0,707 >0,05. Dari hasil ini dapat disimpulkan bahwa strategi bisnis tidak memotivasi manajemen Yarsi Sumbar dalam melakukan manajemen laba. Hal ini dikarenakan strategi bisnis yang meliputi dokumen perencanaan yang sebelumnya telah disusun oleh Yarsi Sumatera Barat tidak dilaksanakan sesuai dengan yang tertulis dalam dokumen perencanaan tersebut. Ini terjadi diakibatkan bahwa fakta yang ditemukan dilapangan sering tidak sesuai dan berbeda dengan kebutuhan yang ada di dokumen perencanaan, sehingga ada beberapa responden yang menjawab tidak setuju atas item pernyataan yang disajikan.

Hasil penelitian ini selaras dengan penelitian yang telah dilakukan oleh Wardani dan Isbela (2017) dan penelitian Daud, et al (2020), Hasil penelitiannya menunjukkan bahwa strategi bisnis tidak berpengaruh secara signifikan terhadap manajemen laba tetapi berbeda dengan penelitian oleh Puspita (2018) yang menunjukkan bahwa strategi bisnis berpengaruh terhadap manajemen laba.

\section{Pengaruh Pendelegasian Wewenang Terhadap Manajemen Laba}

Berdasarkan hasil analisis statistik pada uji T menunjukkan bahwa hipotesis kedua (H2) ditolak dan dapat disimpulkan bahwa pendelegasian wewenang tidak berpengaruh terhadap manajemen laba. Hal ini dilihat dari nilai $\mathrm{t}$ hitung 1,280 < t tabel 2,016 dan nilai signifikansi sebesar 0,208 > 0,05. Hal ini membuktikan bahwa pendelegasian wewenang yang dilakukan oleh delegator kepada delegate terbukti tidak membuka peluang bagi manajerial dalam melakukan manajemen laba di Yarsi Sumbar. Pendelegasian wewenang di Yarsi Sumatera Barat belum sepenuhnya dijalankan dengan baik. Hal ini dilihat dari hasil jawaban angket yang dikembalikan dimana pengurus memberikan jawaban sangat tidak setuju dan tidak setuju atas angket yang disajikan. Delegasi wewenang yang dilakukan oleh pimpinan kepada bawahannya belum berdasarkan pada persyaratan yang memadai, artinya posisi-posisi yang dijabat oleh delegate belum memiliki kualifikasi dibidangnya.

Hasil penelitian ini selaras dengan penelitian Puspita (2018) manajemen laba tidak berpengaruh terhadap kinerja perusahaan, sehingga perusahaan yang melakukan praktek manajemen laba maupun tidak melakukan praktek manajemen laba tetap akan mengalami peningkatan atau penurunan kinerja perusahaan. Hasil penelitian ini berbeda dengan penelitian Hermawan (2019), Fazira dan Erdawati (2019) 
yang menunjukkan bahwa pendelegasian wewenang berpengaruh positif signifikan terhadap kinerja manajerial.

\section{Pengaruh Kepemimpinan Terhadap Manajemen Laba}

Berdasarkan hasil pengujian kepemimpinan terhadap manajemen laba pada uji T menunjukkan bahwa hipotesis ketiga (H3) ditolak dan dapat disimpulkan bahwa kepemimpinan berpengaruh negatif terhadap manajemen laba. Hal ini dilihat dari nilai t hitung $-3,312<\mathrm{t}$ tabel 2,016 dan nilai signifikansi sebesar $0,002<0,05$. Hasil tersebut menunjukkan bahwa apabila kepemimpinan di Yarsi dijalankan dengan baik maka akan mengurangi motivasi manajemen melakukan manajemen laba. Kepemimpinan di Yarsi Sumatera Barat terlihat sudah baik dan efektif. Hal ini dibuktikan dari jawaban rata-rata responden setuju dan sangat setuju terhadap item pertanyaan kepemimpinan yang disajikan dan diperjelas melalui wawancara yang telah dilakukan. Kepemimpinan di Yarsi mampu mempengaruhi para bawahannya untuk bekerja lebih baik sehingga dapat meningkatkan kinerja yayasan tersebut.

Hasil dalam penelitian ini berbeda dengan penelitian Lina (2014), penelitian Suryana, et al (2010), Hasibuan dan Bahri (2018) yang menunjukkan bahwa kepemimpinan mempunyai pengaruh positif terhadap kinerja organisasi.

\section{Pengaruh Kebijakan Manajemen Keuangan Terhadap Manajemen Laba}

Berdasarkan hasil analisis statistik pada uji T menunjukkan bahwa hipotesis keempat (H4) ditolak dan dapat disimpulkan bahwa kebijakan manajemen keuangan tidak berpengaruh positif terhadap manajemen laba. Hal ini dilihat dari nilai t hitung 0,803 < t tabel 2,016 dan nilai signifikansi sebesar 0,426>0,05. Hal ini membuktikan bahwa pemilihan kebijakan manajemen keuangan yang disusun oleh Yarsi Sumbar tidak mempengaruhi manajerial dalam melakukan manajemen laba di yayasan tersebut. Kebijakan manajemen keuangan yang telah ditetapkan oleh Yarsi tidak sepenuhnya dijalankan sesuai dengan ketentuan yang telah ditetapkan. Terdapat beberapa kebijakan seperti penerimaan kas disetorkan pada hari yang sama ke bank dan pembayaran yang melebihi 500 ribu melalui transfer bank pada praktiknya belum diterapkan. Hal ini dilihat dari jawaban responden tidak setuju terhadap item pernyataan pada angket yang disajikan.

Hasil penelitian ini berbeda dengan hasil penelitian Cahyaningdyah dan Ressany (2012) yang menunjukkan adanya pengaruh kebijakan manajemen keuangan terhadap nilai perusahaan dan penelitian oleh Murtini (2008) Menunjukkan kebijakan manajemen keuangan (keputusan pendanaan dan keputusan investasi berpengaruh terhadap nilai perusahaan. 


\section{Pengaruh Manajemen Likuiditas Terhadap Manajemen Laba}

Berdasarkan hasil analisis statistik pada Uji T menunjukkan bahwa hipotesis kelima (H5) ditolak dan dapat disimpulkan bahwa likuiditas tidak berpengaruh positif terhadap manajemen laba. Hal ini dilihat dari nilai t hitung $1,683<\mathrm{t}$ tabel 2,016 dan nilai signifikansi sebesar 0,109. Nilai signifikansi tersebut lebih besar dari 0,05 . Hal ini membuktikan bahwa bahwa tinggi rendahnya rasio likuiditas tidak mempengaruhi manajerial dalam melakukan manajemen laba di Yarsi Sumatera Barat. Ini menunjukkan bahwa tinggi rendahnya rasio likuiditas di Yarsi tidak mempengaruhi manajemen untuk melakukan manajemen laba. Manajemen Yarsi lebih memperhatikan faktor yang menentukan likuiditas seperti aktivitas pendanaan, aktivitas operasi dan aktivitas investasi dibandingkan manajemen laba untuk menurunkan atau meningkatkan rasio likuiditasnya.

Hasil penelitian ini selaras dengan penelitian Nurakhiroh, dkk (2014) yang menunjukkan bahwa likuiditas tidak berpengaruh terhadap manajemen laba. Namun tidak selaras dengan penelitian Prastiani (2018) dan penelitian Rahman (2019) yang menyebutkan bahwa likuiditas berpengaruh terhadap manajemen laba

\section{Pengaruh Strategi Bisnis, Pendelegasian Wewenang, Kepemimpinan, Kebijakan Manajemen Keuangan, Dan Manajemen Likuiditas Terhadap Manajemen Laba}

Hasil pengujian statistik yang dilakukan dalam penelitian ini (dapat dilihat pada Uji F) menunjukkan nilai signifikansi yang dihasilkan adalah sebesar 0,021. Nilai signifikansi tersebut lebih kecil dari nilai toleransi kesalahan 0,05 dan nilai $\mathrm{F}$ sebesar 3,000. Maka berdasarkan hasil tersebut dapat disimpulkan bahwa hipotesis enam (strategi bisnis, pendelegasian wewenang, kepemimpinan, kebijakan manajemen keuangan, dan manajemen likuiditas secara simultan berpengaruh terhadap manajemen laba) diterima.

Berdasarkan hasil penelitian diatas, dapat disimpulkan bahwa hanya variabel kepemimpinan yang berpengaruh negatif secara parsial terhadap praktik manajemen laba di Yarsi sumbar. Variabel lainnya seperti strategi bisnis, pendelegasian wewenang, kebijakan manajemen keuangan, dan manajemen likuiditas tidak berpengaruh terhadap manajemen laba di Yarsi sumbar. Namun secara simultan (bersamasama) variabel independen (strategi bisnis, pendelegasian wewenang, kepemimpinan, kebijakan manajemen keuangan, dan manajemen likuiditas) berpengaruh terhadap variabel dependen (manajemen laba). 


\section{Kesimpulan}

Penelitian ini bertujuan untuk mengetahui pengaruh strategi bisnis, pendelegasian wewenang, kepemimpinan, kebijakan manajemen keuangan, dan manajemen likuiditas terhadap manajemen laba di Yarsi Sumbar. Berikut hasil penelitian yang telah dilakukan, menunjukkan bahwa:

1) Strategi bisnis tidak berpengaruh positif terhadap manajemen laba

2) Pendelegasian wewenang tidak berpengaruh positif terhadap manajemen laba.

3) Kepemimpinan berpengaruh negatif terhadap manajemen laba

4) Manajemen likuiditas tidak berpengaruh positif terhadap manajemen laba

5) Strategi bisnis, pendelegasian wewenang, kepemimpinan, kebijakan manajemen keuangan, dan manajemen likuiditas secara bersama berpengaruh terhadap manajemen laba

\section{Keterbatasan Penelitian}

Penelitian ini memiliki keterbatasan-keterbatasan yang sekaligus dapat menjadi arahan bagi penelitian yang akan datang antara lain:

1) Penelitian ini hanya melibatkan satu perusahaan yakni Yarsi Sumatera Barat sehingga responden yang digunakan terbatas.

2) Variabel-variabel yang mempengaruhi manajemen laba dalam penelitian ini belum sepenuhnya diteliti sebesar 82,8\% masih dijelaskan oleh faktor lain. Dengan demikian perlu adanya penambahan faktor lainnya dalam penelitian selanjutnya seperti komitmen organisasi, leverage dan profitabilitas agar variabel-variabel yang mempengaruhi manajemen laba dapat dibandingkan dan terpenuhi. Peneliti tidak dapat melakukan pengujian variabel ini karena keterbatasan data.

\section{Daftar Pustaka}

Astari, Anak A dan I Ketut Suryanawa. 2017. Faktor-faktor yang mempengaruhi manajemen laba. Jurnal Akuntansi Universitas Udayana.

Cahyaningdyah, Dwi dan Ressany. 2012. Pengaruh Kebijakan Manajemen Keuangan Terhadap Nilai Perusahaan. Jurnal Dinamika Manajemen Universitas Negeri Semarang.

Chaerunesia, W., Sutra, P R dan Wahyudi S. M. 2018. Pengaruh Good Corporate Governancedan Financial Distress Terhadap Manajemen Laba Pada Perusahaan Indonesia Yang Masuk Dalam Asean Corporate Governance Scorecard. Jurnal Komunikasi Ilmiah Akuntansi dan Perpajakan\ 
Daud, Darsun., Askandar, NS dan Junaidi. 2020. Pengaruh Strategi Bisnis Terhadap Manajemen Laba Dengan Kinerja Perusahaan Sebagai Variabel Intervening. Jurnal Fakultas

Ekonomi dan Bisnis Universitas Negeri Malang.

Fadli, Khairul. 2019. Pengaruh Manajemen Laba Terhadap Relevansi Nilai Informasi Akuntansi Pada Pt. Pln (Persero) Wilayah Sumatera Utara. Skirpsi Universitas Medan Area

Fazira, R dan Erdawati L. 2019. Pengaruh Pendelegasian Wewenang Dan Komitmen Organisasi Terhadap Kinerja Manajerial Pada Organisasi Perangkat Daerah Pemerintah Kota Tangerang. Jurnal Ekonomi dan Bisnis.I

Ghozali, Imam. 2018. Aplikasi Analisis Multivariate dengan Program IBM SPSS 25 Edisi 9. Semarang: Universitas Diponegoro

Hasibuan, S.M dan Bahri, Syaiful. 2018. Pengaruh Kepemimpinan, Lingkungan Kerja dan Motivasi Kerja Terhadap Kinerja. Jurnal Ilmiah Magister Manajemen.

Hermawan, Eddy. 2019. Pengaruh Kompetensi, Pendelegasian Wewenang dan Kepuasan Kerja Terhadap Kinerja Aparatur Sipil Negara. Jurnal Ilmiah Magister Manajemen. 2(2).

Hery. 2015. Pengantar Akuntansi. Jakarta: Grasindo

Indrianto, Nur dan Bambang Supomo. 1999. Metodologi Penelitian Bisnis Untuk Akuntansi dan Manajemen. Yogyakarta: BPFE

Jensen, M. C dan William H. M. 1976. Theory Of The Firm: Managerial Behavior, Agency Costs And Ownership Structure. Journal of Financial Economics

Juhana J, Sadu. W dan Irwan.T.K. 2020. Pengaruh Pelimpahan Wewenang, Alokasi Anggaran Dan Kepemimpinan Terhadap Terhdap Kinerja Kecamatan di Kabupaten Garut. Jurnal Papatung

Kawedar, Warsito. 2005. Sikap Etis Akuntan Dan Pengguna Jasa Akuntan Terhadap Praktik Manajemen Laba. Jurnal Akuntansi dan Auditing, Vo1 (2).

Martini, Umi. 2008. Pengaruh Kebijakan Manajemen Keuangan Terhadap Nilai Perusahaan. Jurnal Riset Akuntansi dan Keuangan. Universitas Kristen Duta Wacana, 4(1).

Meidiyustiani, Rinny. 2016. Pengaruh Modal Kerja, Ukuran Perusahaan, Pertumbuhan Penjualan dan Likuiditas Terhadap Profitabilitas Pada Perusahaan Manufaktur Sektor Industry Barang Konsumsi Yang Terdaftar Di Bursa Efek Indonesia (BEI) Periode Tahun 2010-2014. Jurnal Akuntansi Keuangan. 5(2).

Mowen M Maryanne, Don R. Hansen, Dan L. Heitger. Dasar- Dasar Akuntansi Manajerial Edisi 5. Jakarta: Salemba Empat. 
Muttaqin, G Fajar. 2018. Pengaruh Pendelegasian Wewenang Terhadap Kinerja Organisasi. Jurnal Akuntansi Riset Dan Terpadu. 11(2)

Niranda, Gavra N dan Dul Muid. 2020. Analisis Faktor-Faktor Yang Mempengaruhi Manajemen Laba (Studi Empiris Perusahaan Manufaktur Yang Terdaftar Di Bursa Efek Indonesia Tahun 2016-2017). Jurnal akuntansi universitas diponegoro, 9(2).

Nugroho, Elfianto. 2011. Analisis Pengaruh Likuiditas, Pertumbuhan Penjualan, Perputaran Modal Kerja, Ukuran Perusahaan Dan Leverage Terhadap Profitabilitas Perusahaan. Skirpsi Universitas Diponegoro

Nurakhiroh, T., Fachrurrozie, Prabowo Y.J. 2014. Pengaruh Rasio Keuangan Terhadap Rating Sukuk dengan Manajemen Laba Sebagai Variabel Intervening. Accounting Analysis Journal

Paylosa, Fanny. 2014. Pengaruh Strategi Bisnis dan Desentralisasi Terhadap Hubungan Antara Pemanfaatan Informasi Sistem Akuntansi Manajemen dan Kinerja Manajerial. Skripsi Universitas Negeri Padang

Prasetya, Harris. 2013. Pengaruh Ukuran Perusahaan, Profitabilitas, Financial Leverage, Klasifikasi Kap Dan Likuiditas Terhadap Praktik Perataan Laba. Skripsi Universitas Diponegoro

Prastiani, S.C. 2018. Pengaruh Kinerja Keuangan Terhadap Peringkat Obligasi dengan Manajemen Laba Sebagai Variabel Intervening Pada Perusahaan Manufaktur Yang Terdaftar di BEI. Jurnal Akuntansi Berkelanjutan Indonesia, 1(1).

Puspita, A.M. 2018. Pengaruh Strategi Bisnis Terhadap Kinerja Perusahaan Dengan Manajemen Laba Sebagai Variabel Intervening. Skripsi Universitas Lampung

Putra, Y.D dan Ni L.P.W. 2013. Pengaruh Likuiditas Dan Leverage Terhadap Profitabilitas dan Nilai Perusahaan Pada Perusahaan Perbankan di BEI. Jurnal Wawasan Manajemen.

Rahman, Abdul. 2019. Pengaruh Profitabilitas, Likuiditas, Leverage, Dan Firm Size Terhadap Peringkat Sukuk Dengan Manajemen Laba Sebagai Variabel Intervening. Skripsi

Ririn R.N. 2015. Analisis Dan Perancangan System Informasi Manajemen Keuangan Rumah Sakit Berbasis Web. Skripsi. Universitas Negeri Alauddin.

Sanjaya, I. P dan Raharjo A. B. 2006. Uji Beda Manajemen Laba Sebelum Dan Selama Krisis Di Indonesia. Jurnal Universitas Atma Jaya Yogyakarta.

Saraswati, Erwin. 2018. Efisiensi dan Efektivitas Manajemen Keuangan Daerah. Simposium Nasional Keuangan Negara. 
Sari, Novita S. K. 2012. Pengaruh Kinerja Keuangan Terhadap Manajemen Laba Pada Perusahaan Perbankan Go Public Tahun 2007-2011. Jurnal Universitas Negeri Surabaya

Sugiyono. 1999. Metode Penelitian Bisnis. Bandung: Alfabeta

Sugiyono. 2018. Metode Penelitian Bisnis Pendekatan Kuantitatif, Kualitatif, Kombinasi, dan R\&D Bandung: Alfabeta

Sujarweni, V Wiratna. 2017. Manajemen Keuangan Teori, Aplikasi dan Hasil Penelitian. Yogyakarta: Pustaka Baru Press

Sule, T.E dan Kurniawan Saefullah. 2005. Pengantar Manajemen Edisi Pertama. Jakarta: Prenamedia Group

Sumarni, Murti dan Salamah Wahyuni. 2005. Metodologi penelitian bisnis. Yogyakarta: Andi

Suryana Nana, Siti Haerani, dan Muhammad I Taba. 2010. Pengaruh Kepemimpinan Dan Motivasi Kerja Terhadap Kepuasan Kerja Karyawan Dan Kinerja Perusahaan (Studi Kasus Di Divisi Tambang Pt Inco Sorowako). Jurnal

Soni, G. Somali. 2018. Pengelolaan Yayasan Menurut UU. No 28 Tahun 2004 Tentang Yayasan. Jurnal. Universitas Langlangbuana Bandung. 20(1)

Tika, Pabundu. 2006. Metodologi Riset Bisnis. Jakarta: Bumi Aksara

Undang- Undang No. 28 Tahun 2004. Tentang Perubahan Atas UU No. 16 Tahun 2001 Tentang Yayasan.

Utari D, Ari Purwanti dan Darsono Prawironegoro. 2014. Manajemen Keuangan Kajian Praktik dan Teori dalam Mengelola Keuangan Organisasi Perusahaan. Jakarta: Mitra Wacana Media

Wardani, D.K dan Isbela P.A. 2017. Pengaruh Strategi Bisnis Dan Karakteristik Perusahaan Terhadap Manajemen Laba. Junal Akuntansi.

Wiryadi, Arri dan Nurzi S. 2013. Pengaruh Asimetri Informasi, Kualitas Audit, Struktur Kepemilikan Terhadap Manajemen Laba. Jurnal Akuntansi.

Wulandari, Emilia. A. 2015. Analisis Tingkat Kesehatan Bank. Skripsi Universitas Muhammadiyah Ponorogo 